\title{
Assessing Student Attitudes to Moodle versus Print Materials for L2 Vocabulary Acquisition
}

\author{
John Howrey and Kelly Quinn
}

\begin{abstract}
Past research indicates that learners underutilize second language vocabulary acquisition strategies. This paper presents four different methods of learning English vocabulary from the Academic Word List (AWL), with emphasis on comparing the benefits of print materials versus online Moodle materials. The participants in the project were first year English majors at a private university in Japan. One set of students used print materials: vocabulary cards and in class assessment in the first semester and a vocabulary workbook for out of class practice combined with in class assessment in the second semester. The second set of students used Moodle materials: out of class online Moodle activities in the first semester and a workbook combined with out of class Moodle assessment in the second semester. A pretest and posttest were administered to determine how well students learned the material. Students using the print materials slightly outperformed students using the online materials. A survey was given to assess student attitudes toward the different types of materials and toward the method and style of the activities. This paper will discuss the results of the posttests and learner attitudes survey.
\end{abstract}

Index Terms-Vocabulary acquisition, assessment, online materials, student attitudes.

\section{INTRODUCTION}

Vocabulary acquisition is critical in learning a foreign language. A number of studies have highlighted the importance of learning the 2,000 - 3,000 most frequently used English words so that learners can comprehend most basic written texts and participate in everyday conversations [1]-[3]. In fact, it is often the failure to acquire necessary vocabulary that keeps many students from making the transition from intermediate to advanced levels of proficiency [1], [4], [5]. Additional research asserts that lexical errors, mistakes where the word used is inappropriate in either meaning or style to the context, are the most common and serious errors that language learners make [6] and that the biggest element of learning a new language is learning its vocabulary [7].

One of the challenges of vocabulary acquisition is that L2 learners often underutilize or neglect vocabulary learning strategies [2]. More successful learners tend to use a wider range of strategies than less successful learners, but because there is a lack of training materials available, teachers are often uncomfortable teaching vocabulary learning strategies,

Manuscript received June 7, 2014; revised September 11, 2014.

J. Howrey is with the Nanzan English Education Center (NEEC) at Nanzan University, Nagoya, Japan (e-mail: jhowrey@nanzan-u.ac.jp).

K. Quinn is with the Center for Engineering Education at Nagoya Institute of Technology, Nagoya, Japan (e-mail: quinn@nitech.ac.jp). and students often have fixed ideas about how to study vocabulary. Providing vocabulary learning instruction is not easy [8], but students fixed ideas about how to study may limit their ability to acquire new vocabulary, and teachers need to be aware of how students are studying and what areas of vocabulary knowledge their study methods are neglecting.

Another challenge is deciding what vocabulary to learn. Even if students learn the first 2,000 words of the General Service List [9], research suggests this list only gives students about $80 \%$ coverage of most texts [2], [10]. This means students also need to learn lower frequency words. However, since low frequency words do not appear in the text often enough, some academics have argued that it is better to spend class time on learning strategies, such as guessing from context and using word parts to guess lexical meanings [11]. Although these strategies are helpful, if learners only recognize $80 \%$ of the words in a text, they often do not know enough vocabulary to guess meaning from context, which is so important in vocabulary acquisition [12]-[14].

Yet another challenge is that students need not just receptive knowledge, the ability to understand the words when reading or hearing them, but also productive knowledge, the ability to correctly use the words in oral or written form [5], [15]-[17]. In fact, [18] argues that words that learners cannot use correctly cannot be considered a part of that learner's lexical knowledge. Yet student study habits tend to focus on rote memorization. For example, in one study Japanese students preferred learning strategies such as using a bilingual dictionary, saying a word aloud and written repetition [4] - strategies that focus on only the receptive knowledge of a word.

The final challenge was deciding how to present the materials. Several studies have suggested the importance of preferred study methods to facilitate learning [2] and that learning vocabulary is often decided by students' personal involvement of "time, effort and attention" [19]. To that end we compared traditional in-class vocabulary methods and online Moodle activities which students could access at home or from their mobile phones. Since Moodle activities give students freedom in when and how often they do the activities, provide immediate feedback, and can be done as often as students want, it was believed that students would have a more positive attitude to this approach.

This project then was designed with three main goals: one, to provide students with a variety of vocabulary methods so that they would improve not only receptive knowledge but also productive knowledge of target vocabulary; two, to assess the effectiveness of print and Moodle methods; and three, to examine student attitudes toward different vocabulary learning methods to determine which best suit their learning styles and personalities. 


\section{Methodology}

\section{A. Participants}

The study involved a convenience sample of 35 first year intermediate-level English majors enrolled in a first year English reading class at a private university in Japan. The classes were streamed by ability so that the high intermediate to advanced students and beginner to low-intermediate students were placed in separate classes. The participants in this project were not selected from the highest or lowest level students. They were chosen from the mid-level students. The classes met once a week for 90 minutes.

\section{B. Materials}

Items from the Academic Word List (AWL) were selected as the target vocabulary for this project. The AWL targets words that are not in the first 2,000 words of the General Service List yet are common across a range of disciplines [20]. The AWL list contains 570 word families divided into 10 sub-lists based on their frequency. Sub-lists 1 to 9 contain 60 word families each and Sub-list 10 contains 30 . In each sub-list, the headwords are the stem forms of the words. Other forms of the words are listed and in most versions of the list, the most common form of the headword is in italics. The headword is often, but not always, the most common. In the past decade The AWL has become a commonly used academic word list in textbooks [21]. Although researchers such as [22] point out that students often have better recall with words that are self-selected, words lists are commonly used in Japanese high schools and universities [4]. Since the AWL is a fairly small set of words and is supposed to provide the additional coverage that students need to reach 90-95 coverage of a text [19], it was chosen for our students. However, the authors decided to use words from the higher sub-lists to target more unfamiliar words. In the first semester, students studied words from Sub-lists 6 and 7 and in the second semester, they studied Sub-list 8.

\section{Procedure}

At the beginning of the semester, in both the paper-based and Moodle classes, students were given a pretest. The pretest included the material and type of activities used in the activities: definition matching, word form chart completion, and fill-in-the-blank exercises. At the end of the semester, the same test was given as a posttest to determine to what degree students had mastered the skills and materials presented in the activities during the semester.

\section{1) Paper-based materials}

In the first semester of the paper-based class, there were two types of activities: definition matching and fill-in-the-blank activities. Students were given 20 words every three weeks and made vocabulary cards for them which were to include the English and Japanese definitions, each word's part of speech, other parts of speech of the word, and a few collocations. For example, for the word "research" a student card may have included word forms "research(v)," "research(n)," and "researcher(n)," collocations such as "conduct research," "do research," and "research on," and a brief English and Japanese definition.

Students quizzed each other at the start of each class for five minutes by exchanging their vocabulary cards with a partner and were given a definition matching exercise as homework to help practice learning the words in context. A week later, students were quizzed to match definitions of each word from a list of four options and to complete a word form chart and a fill-in-the-blank exercise. The following week, students were given a fill-in-the-blank quiz similar to the one they had done for practice for which they received a grade. Students were also given a midterm of the first 60 words and a comprehensive exam at the end of the semester. Students also sometimes played vocabulary games in which they had to identify different parts of speech of targeted vocabulary by writing words on the board. This was done to review vocabulary and reinforce correct spelling.

In the second semester, instead of doing vocabulary cards, students were given a workbook. Each of the twelve units of the workbook targeted five words and provided definition matching, word form charts which students had to complete, fill-in-the-collocation practice, and error correction. Students were given the workbook on the first day of class and were assigned a unit (three pages) each week. Students would complete the workbook activities on their own as homework and then in class check the answers in small groups or ask the teacher for the answers to problems that they were unsure of. Sometimes additional collocations or sample sentences were provided. Class time for checking workbooks took roughly 15 minutes a week. Students were also given a midterm exam of the first six units and a comprehensive exam at the end of the term.

\section{2) Online materials}

In the first semester of the online Moodle class, there were three types of activities: a definition matching activity, a word form activity, and a fill in the blank activity. The AWL does not include definitions or word form information so the first order of business was to teach the students the most common English definitions for the words. Students were given an English definition and then had to choose the most appropriate word to match the definition. If a word had multiple definitions or if the meaning of the word significantly changed for different word forms, an additional quiz problem was included for each meaning. For the word form activity, students had to change the form of the head word to its different forms. For example, students were given the word "allocate" and asked to write the noun form "allocation" and the past participle form "allocated." Word forms that indicated people and forms that used prefixes to make forms with opposite meanings were also required. For example, students were prompted to provide the opposite form of the word "accurate," "inaccurate." For the fill in the blank activity, students were provided with scrambled versions of the head words. They had to unscramble the words and use the correct form of the word to complete a sentence. Two quizzes were given during the semester and at the end of the semester a comprehensive exam was given.

In the second semester, the same workbook for the print-based class was used in the Moodle class. Students downloaded a pdf of the workbook activities which they could use offline, but to check their answers, they had to access the online version on the Moodle site. No answers were given in class and except when the students encountered 
some technical issue with the Moodle site, no class time was committed to the vocabulary activities. Two quizzes were given during the semester.

\section{Student Survey}

At the end of the second semester, students were given a questionnaire which included Likert-scale items about the level of difficulty of the materials, their perceived usefulness, whether they felt the materials should be used in future reading courses, and which activities and methods they preferred using. It also included open-ended questions concerning the amount of time spent using the materials, what they liked or disliked about the project, and how they felt the materials could be improved.

\section{RESULTS}

\section{A. Pretest and Posttest Results}

The pretest and posttest in the first semester tested students' ability to match definitions and complete fill-in-the-blank exercises, essentially testing whether students could not only identify the correct word to complete the passage based on the context or collocation but also identify the correct part of speech of the word. Thus, the first half of the test examined students' receptive knowledge of the target vocabulary whereas the second half examined the students' productive knowledge.

The results of the pretest and posttest scores for the first semester are summarized in Table I. In both the paper-based and Moodle activities students showed improvement. Students in the paper-based class performed slightly better than the Moodle group, though it should be noted they had a slightly higher average on the pretest, too.

\begin{tabular}{lccc}
\multicolumn{4}{c}{ TABLE I: FIRST SEMESTER PRETEST AND POSTTEST RESUlTS } \\
\hline \hline \multirow{2}{*}{ Class } & $\begin{array}{c}\text { Pretest } \\
\text { Average }\end{array}$ & $\begin{array}{c}\text { Posttest } \\
\text { Average }\end{array}$ & Change \\
\hline Paper-based & $18 \%$ & $75 \%$ & $57 \%$ \\
Moodle-based & $17 \%$ & $69 \%$ & $52 \%$ \\
\hline \hline
\end{tabular}

The results of the two parts of the pretest and posttest, definition matching and fill-in-the-blank sentence completion, are summarized in Table II and Table III. Here, we see that students did not have much receptive knowledge of the target vocabulary before the class began, scoring only an average of 29\% (paper-based) and 23\% (Moodle) on the pretest.

TABLE II: FIRST SEMESTER DEFINITION MATChING PRETEST AND PostTest RESUlts

\begin{tabular}{lccc}
\hline \hline \multirow{2}{*}{ Class } & $\begin{array}{c}\text { Pretest } \\
\text { Average }\end{array}$ & $\begin{array}{c}\text { Posttest } \\
\text { Average }\end{array}$ & Change \\
\hline Paper-based & $29 \%$ & $92 \%$ & $63 \%$ \\
Moodle-based & $23 \%$ & $79 \%$ & $56 \%$ \\
\hline \hline
\end{tabular}

Their productive knowledge of the vocabulary was even lower. Curiously, the paper-based class scored only an average of $7 \%$ on sentence completion whereas the Moodle class, despite the lower percentage on definition matching, scored slightly higher, averaging $12 \%$. Both groups scored nearly identical results on the posttest, however.
TABLE III: FIRST SEMESTER SENTENCE COMPLETION PRETEST AND POSTTEST RESUlTS

\begin{tabular}{lccc}
\hline \hline Class & $\begin{array}{c}\text { Pretest } \\
\text { Average }\end{array}$ & $\begin{array}{c}\text { Posttest } \\
\text { Average }\end{array}$ & Change \\
\hline Paper-based & $7 \%$ & $59 \%$ & $52 \%$ \\
Moodle-based & $12 \%$ & $58 \%$ & $46 \%$ \\
\hline \hline
\end{tabular}

The pretest and posttest in the second semester tested students' ability to complete a word family chart and answer fill-in-the-blank exercises. The word family chart was added to the pretest and posttest and to the in class and outside class workbooks to help improve students' scores in the fill-in-the-blank exercises. Students still had to match definitions in the workbooks, but it was not tested in the second semester. Students need to know the meaning of the word to complete the fill-in-the-blank activities, so it was believed that a separate definition section was unnecessary.

The results of the second semester were similar to the first semester and are summarized in Table IV. Students in the paper-based class again slightly outperformed students in the Moodle class on the posttest.

TABLE IV: SECOND SEMESTER PRETEST AND POSTTEST RESUlTS

\begin{tabular}{lccc}
\hline \hline Class & $\begin{array}{c}\text { Pretest } \\
\text { Average }\end{array}$ & $\begin{array}{c}\text { Posttest } \\
\text { Average }\end{array}$ & Change \\
\hline Paper-based & $34 \%$ & $78 \%$ & $44 \%$ \\
Moodle-based & $34 \%$ & $72 \%$ & $38 \%$ \\
\hline \hline
\end{tabular}

The results for the word family charts and fill-in-the-blank exercises are summarized in Table V and Table VI.

TABLE V: SECOND SEMESTER WORd CHART PRETEST AND POSTTEST

\begin{tabular}{lccc}
\multicolumn{4}{c}{ RESULTS } \\
\hline \hline \multirow{2}{*}{ Class } & Pretest & Posttest & Change \\
& Average & Average & \\
\hline Paper-based & $42 \%$ & $86 \%$ & $44 \%$ \\
Moodle-based & $42 \%$ & $79 \%$ & $45 \%$ \\
\hline \hline
\end{tabular}

TABLE VI: SECOND SEMESTER SENTENCE COMPLETION PRETEST AND POSTTEST RESULTS

\begin{tabular}{lccc}
\hline \hline Class & $\begin{array}{c}\text { Pretest } \\
\text { Average }\end{array}$ & $\begin{array}{c}\text { Posttest } \\
\text { Average }\end{array}$ & Change \\
\hline Paper-based & $24 \%$ & $69 \%$ & $45 \%$ \\
Moodle-based & $23 \%$ & $63 \%$ & $40 \%$ \\
\hline \hline
\end{tabular}

One noteworthy point here is that the inclusion of additional activities such as word charts, collocations and error correction in the paper-based and online workbooks helped students score better in the sentence completion activities. These results suggest that for students to gain more productive knowledge of a word, students need to use additional vocabulary strategies and/or practice using the words whether in print or online.

\section{B. Survey Results}

From their responses on the postproject survey, students in the print-based class reported that they found the workbook materials more useful $(4.47, \mathrm{SD}=0.51)$ and favorable to the vocabulary cards $(3.4, \mathrm{SD}=1.00)$. On a scale of 1 to 5 , with 1 indicating "strongly disagree" and 5 indicating "strongly agree," they also evaluated each of the activities, which are summarized in Table VII.

Students found the collocation exercises the most useful and the word form chart the least useful. However, it should 
be noted that the word chart scored more favorably than the vocabulary cards. Students also reported that they spent more time studying the workbook (an average of 38 minutes a week) compared to the vocabulary cards (an average of 12 minutes a week), which is not surprising in itself since the workbook had more exercises, but the difference in time could also be an indication that direct instruction regarding the importance of word forms and collocations will result in more study time. The amount of time students spent completing the Moodle activities is summarized in Table VIII.

TABLE VII: PERCEPTIONS OF USEFULNESS

\begin{tabular}{lcc}
\hline \hline Survey Question & Mean & SD \\
\hline $\begin{array}{l}\text { I think the definition matching was useful for } \\
\text { learning vocabulary. }\end{array}$ & 4.17 & 0.95 \\
$\begin{array}{l}\text { I think the word form chart was useful for } \\
\text { learning vocabulary. }\end{array}$ & 3.94 & 1.02 \\
$\begin{array}{l}\text { I think the fill-in-the-blank activities were useful } \\
\text { for learning vocabulary. }\end{array}$ & 4.17 & 0.63 \\
$\begin{array}{l}\text { I think the collocation practice was useful for } \\
\text { learning vocabulary. }\end{array}$ & 4.4 & 0.50 \\
$\begin{array}{l}\text { I think the error correction was useful for } \\
\text { learning vocabulary. }\end{array}$ & 3.47 & 0.94 \\
\hline \hline & & \\
\hline \hline
\end{tabular}

With the Moodle activities, there is a consistent and steady decline in the amount of time studying online and the number of times students attempted the activities. With the AWL Activities Level 8, it should be remembered that students had been given the activities as a downloadable PDF and so students only had to access the Moodle site to check their answers. After attempting the quizzes in Level 8, the correct answers were shown to the students. This is different from the activities in Level 6 and 7 where students could make multiple attempts, but were only shown whether their answers were correct or incorrect. Some of the decline may be attributed to greater familiarity with the interface and more efficient studying of the items. However, the lack of attempts at Level 8 indicates that many students did not find the online activities a convenient way to review, preferring instead to review using the PDF.

Students also were asked open-ended questions about the materials in both the print-based and Moodle classes, and comments like the ones below were common.

In both the paper-based class and the Moodle class students found the material challenging. Comments such as, "The vocabulary was difficult and a little too much," and "I am bad at memorizing vocabulary and so this was difficult for me," were common in the Moodle class. In the paper-based class, comments such as, "The workbook was difficult," were common.

Comments such as, "I did not know any of these words," seem to indicate that students found the words difficult and beyond their experience. Teachers may interpret the comment positively as evidence of the value and appropriateness of the items selected, but it seems that students found lists composed entirely of new words daunting. More students in the Moodle commented that the words were difficult. This may be an indication of the frustration of being unable to get the correct answer from the online materials or difficulty with the online interface. Still two students in the Moodle class commented directly, "The level of the words was appropriate."

TABLE IX: SUMMARY OF TYPE AND NUMBER OF STUDENT COMMENTS

\begin{tabular}{lcc} 
Type of Comment & $\begin{array}{c}\text { Paper- } \\
\text { based }\end{array}$ & Moodle \\
\hline $\begin{array}{l}\text { The level of the words was appropriate. } \\
\text { The level of the words was "difficult" or "too } \\
\text { difficult." }\end{array}$ & 12 & 15 \\
$\begin{array}{l}\text { The amount of material was appropriate. } \\
\text { The amount of material was excessive. }\end{array}$ & 4 & 2 \\
$\begin{array}{l}\text { The style and method of the study materials } \\
\text { was useful. }\end{array}$ & 8 & 3 \\
The style and method of the study materials & 1 & 4 \\
was flawed. & 8 & 8 \\
The overall experience was positive. & 0 & 0 \\
The overall experience was negative. &
\end{tabular}

More students in the Moodle class also commented that the amount of work was excessive. "The amount of work was a little too much," or "There were a lot of vocabularies [sic]," were two of the comments. This again could be due to the nature of the online activities where students were encouraged to continue until they were able to get the correct answer. Still there were comments like, "The level and usefulness is appropriate."

Looking at the comments, students in the paper-based class were more enthusiastic about the method of instructed than those in the Moodle class. They wrote comments such as, "I could learn more than the basic meaning of the word." And "I didn't do collocations for my vocabulary cards, but now I see they are important." In the Moodle class comments such as, "Moodle is a new way of studying for me. It is interesting," and "The Moodle quizzes were fun for me," indicate that at least some students found the online materials engaging and interesting.

In the paper-based class, there was only one comment saying that the style and method of the study materials was flawed, "I don't like to check answers in class." Unfortunately the writer of the comment did not expound on the reasons for this and we can't know the source of their dislike. Perhaps they felt it was not an efficient use of class time or perhaps they were embarrassed by their lack of knowledge. We just don't know. In the paper-based class, there were a number of useful suggestions for improving the system. Students wrote, "We did practice quizzes in class first semester. I want to do them in second semester too," and "I want more problems." Both of these issues can be addressed in the future.

The Moodle students' claims were often related to technical issues. Students wrote, "There were times when I could not access the site." There were times when the site was down because of server trouble. Also, students often wanted to use their smartphones to complete the activities and there 
were times, such as when they were riding the train to school, when it was impossible to connect because they were moving. Using the smartphone could also incur data fees that could be a burden financially to the students. Students in the Moodle class also admitted that they printed out the web pages and used the paper version to study while commuting. Other students wrote simply, "I often forgot to do the Moodle activities." This speaks to the problem of independent study outside of class. Without reminders and in class accountability, it seems easy for students to forget the online materials and to fall behind.

On a positive note, many students in both classes wrote that they found studying the vocabulary useful and a positive experience. Students in the paper-based class wrote, "I need to study vocabulary. The activities are useful." And "I could learn more than the basic meaning of the word." And "I felt that I could level up by [sic] vocabulary because of this class." These are positive endorsements of the value of studying vocabulary beyond the simple meaning of words and expanding students' awareness of what learning a word means.

In the Moodle class, students wrote, "It was good that I was able to learn many new words." And "Thanks to the vocabulary activities, I get [sic] new words little by little." Even in anonymous surveys it is common for students to write something positive or to claim that despite being challenging the experience was a good one. Still, the number of positive expressions indicates that students value studying vocabulary and recognize the importance of vocabulary acquisition to achieving their language goals.

\section{CONCLUSION}

Vocabulary acquisition remains a critical obstacle for students who wish to improve their language proficiency. From the results on the posttests, we can feel confident that we achieved the first of our goals for the project. Students' knowledge of new vocabulary and their ability to use the words productively improved in both classes. As for the second goal, assessing the benefits of print and Moodle materials, it seems that giving students additional vocabulary practice and reinforcing their learning through time spent in class was the most successful approach. By doing the activities in class, teachers demonstrate their importance and peer pressure from classmates can motivate students to keep up with the activities in a way that Moodle activities which students are left to do by themselves might not. Still, because the overall scores were so similar, advocates of the benefits of Moodle learning can be encouraged that results roughly equal to those obtained through classroom work can be obtained online.

According to the results of the student survey and comments, it can be seen that students find print materials more comfortable and convenient. This is surprising given the ubiquitous nature of digital materials. Perhaps as students become more comfortable and improvements are made in the reliability and convenience of online materials such as those through Moodle, students attitudes will change, but for now, at least with these students, paper is still the preferred method of studying.

Admittedly, due to the small sample size and short duration of the project, it is difficult to make generalizations or recommendations. However, for instructors planning to use Moodle or similar online tools for vocabulary instruction, a blended class, one which uses Moodle outside of class with explicit instruction in class, might be a better approach. Relying on online sources such as Moodle might be less effective unless it is supported by some instruction or practice in class. It is our hope that this project will be of interest to instructors who are considering using Moodle or other online approaches to vocabulary teaching.

\section{REFERENCES}

[1] B. Laufer and I. S. P. Nation, "Vocabulary," in The Routledge Handbook of Second Language Acquisition, S. M. Gass and A. Mackey, Eds., England: Routledge, 2012, pp. 163-176.

[2] I. S. P. Nation, Learning Vocabulary in Another Language, Cambridge: Cambridge, 2001, pp. 14-16, 383.

[3] D. Willis, The Lexical Syllabus, London and Glasgow: Collins, p. 47.

[4] N. Schmitt, "Vocabulary learning strategies," in Vocabulary: Description, Acquisition and Pedagogy, N. Schmitt and M. McCarthy, Eds., Cambridge: Cambridge Press, 1997, pp. 199-227.

[5] M. Swain, "Integrating language and content in immersion classrooms," The Canadian Modern Language Review, vol. 52, no. 4, pp. 529-548, 1996.

[6] S. M. Gass and L. Selinker, Second Language Acquisition, 2nd ed., London: Lawrence Erlbaum, 2001, pp. 372-374.

[7] A. Vermeer, "Exploring the second language learner lexicon," in The Construct of Language Proficiency, L. Verhoeven and J. H. A. L. de Jong, Eds., Amsterdam: John Benjamins, pp. 147-162.

[8] J. Ranalli, "Prospects for developing L2 students' effective use of vocabulary learning-strategies via web-based training," CALICO Journal, vol. 27, no. 1, pp. 161-186, September 2009.

[9] M. West, A General Service List of English Words, London: Longman, Green and Company, 1953.

[10] I. S. P. Nation and R. Waring, "Vocabulary size, text coverage and word lists," in Vocabulary: Description, Acquisition and Pedagogy, N. Schmitt and M. McCarthy, Eds., Cambridge: Cambridge Press, 1997, pp. 6-19.

[11] I. S. P. Nation, Teaching and Learning Vocabulary, New York: Newbury House, 1990

[12] L. Na and I. S. P. Nation, "Factors affecting guessing vocabulary in context," RELC Journal, vol. 16, pp. 33-42, 1985.

[13] E. K. Schatz and R. S. Baldwin, "Context clues are unreliable predictors of word meanings," Reading Research Quarterly, vol. 21, pp. 439-453, 1986.

[14] R. Sternberg, "Most vocabulary is learned through context," in The Nature of Vocabulary Acquisition, M. G. McKeown and M. E. Curtis, Eds., Hillsdale, NJ: Erlbaum, 1987, pp. 89-105.

[15] H. Raptis, "Is second language reading vocabulary best learned by reading?" The Canadian Modern Language Review, vol. 53, no. 3, pp. 556-580, 1997.

[16] T. F. Melka, "Receptive versus productive aspects of vocabulary," in Vocabulary: Description, Acquisition and Pedagogy, N. Schmitt and M. McCarthy, Eds., Cambridge: Cambridge Press, 1997, pp. 6-19.

[17] W. E. Nagy, "Learning words from context," Reading Research Quarterly, vol. 20, pp. 233-253, 1995.

[18] B. Laufer and I. S. P. Nation, "Vocabulary size and use: Lexical richness in L2 written production," Applied Linguistics, vol. 16, no. 3, pp. 307-322, 1995.

[19] C. P. Basanta, "A second-generation CALL vocabulary-learning program ADELEX: In search of a psychopedagogic model," in Insights into Non-native Vocabulary Teaching and Learning, $\mathrm{R}$. Chacon-Beltran, C. Abello-Contesse, and M. Torreblanca-Lopez, Eds., Bristol: Multilingual Matters, pp. 175-185.

[20] A. Coxhead, "A new academic word list," TESOL Quarterly, vol. 34, no. 2, pp. 213-238, 2000.

[21] M. Lessard-Clouston, "Word lists for vocabulary learning and teaching," The CATESOL Journal, vol. 24, no. 1, pp. 287-304, 2012/2013.

[22] R. C. Atkinson, "Optimizing the learning of a second-language vocabulary," Journal of Experimental Psychology, vol. 96, pp. 124-129, 1972. 
John Howrey earned his master's degree in TESL from Bowling Green State University, Ohio, USA in 1998. His academic interests are in rhetoric and composition, writing portfolios, formative feedback, and content-based instruction.

$\mathrm{He}$ is currently an associate professor and a senior language instructor in the Nanzan English Education Center at Nanzan University in Nagoya, Japan. He has been teaching ESL/EFL for over 20 years in both the United States and Japan. He has authored 20 articles including co-authoring the textbook of Introduction to Legal Issues: 40 Hours of Training.

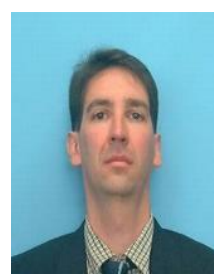

Kelly Quinn earned his master's degree in TESL from Western Michigan University, Michigan, USA in 1992. His academic interests include e-learning, ESP for scientists and engineers, and teaching technical writing. $\mathrm{He}$ is currently an associate professor in the Center for

Engineering Education at Nagoya Institute of Technology in Nagoya, Japan. He has been teaching ESL/EFL for over 20 years in both the United States and Japan. He has authored over 20 articles and several textbooks. He is most recently the author of Japanese History You Should Know. 